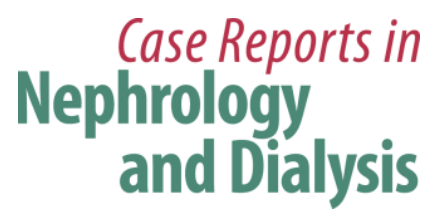

Case Rep Nephrol Dial 2018;8:90-97

DOI: $10.1159 / 000489087$

Published online: May 16, 2018

(C) 2018 The Author(s)

Published by S. Karger AG, Basel

www.karger.com/cnd

This article is licensed under the Creative Commons Attribution-NonCommercial 4.0 International License (CC BY-NC) (http://www.karger.com/Services/OpenAccessLicense). Usage and distribution for commercial purposes requires written permission.

\title{
The Case: Chronic Kidney Disease Unmasked by Single-Subject Research
}

\author{
Benjamin Gollasch ${ }^{\mathrm{a}, \mathrm{b}}$ Oskar Wischnewski ${ }^{\mathrm{c}} \quad$ Birgit Rudolph $^{\mathrm{d}}$ \\ Yoland-Marie Anistan ${ }^{a} \quad$ Friedrich C. Luft ${ }^{a}$ Maik Gollasch ${ }^{\text {a, c }}$

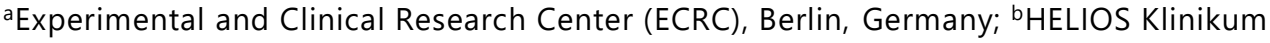 \\ Berlin-Buch, Medical Clinic for Cardiology, Nephrology and Pneumology, Berlin, Germany; \\ 'Medical Clinic for Nephrology and Internal Intensive Care, Campus Virchow, Charité \\ University Medicine, Berlin, Germany; ${ }^{\mathrm{I}}$ nstitute of Pathology, Campus Mitte, Charité \\ University Medicine, Berlin, Germany
}

\section{Keywords}

Focal segmental glomerular sclerosis - Bodybuilder · Next-generation sequencing · Genetic testing

\begin{abstract}
We present a 42 -year-old man with a BMI of 32, who was referred because of proteinuria and decreased renal function. We were impressed by his markedly muscular physique. A renal biopsy was performed, which showed focal segmental glomerular sclerosis (FSGS). Is this patient merely an obese person with FSGS or is something else going on here? We performed extensive clinical and laboratory examinations, genetic testing, and anthropometric data monitoring over time. We transferred our methodology for routine FSGS mutation screening (Sanger sequencing) to the lon Torrent PGM platform with a new custom-targeted NGS gene panel (Ion Ampliseq FSGS panel) and tested the performance of the system in two cohorts of patients with FSGS. We discuss FSGS in bodybuilders, including possible mechanisms, and review the literature.




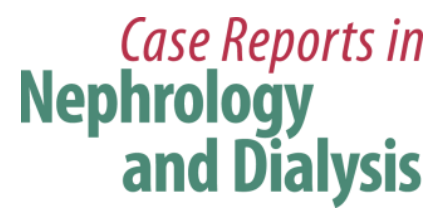

Case Rep Nephrol Dial 2018;8:90-97

DOI: 10.1159/000489087

Gollasch et al.: Chronic Kidney Disease Unmasked

\section{The Case}

A 42-year-old Caucasian man was referred because of proteinuria and decreased renal function. He had developed hypertension several years earlier and was being treated with hydrochlorothiazide and telmisartan. The heart rate was $64 / \mathrm{min}$, while the blood pressure was 146/90 mm Hg. The personal and family histories were negative. His parents, grandparents, and brother had no kidney disease. The patient was $174 \mathrm{~cm}$ tall, weighed $97 \mathrm{~kg}$, and had a BMI of 32. The heart, lungs, abdomen, and neurological examinations were unremarkable. There was no edema. We were impressed by his markedly muscular physique. Laboratory tests revealed a serum creatinine of $6.37 \mathrm{mg} / \mathrm{dL}$ (estimated glomerular filtration rate [CKD-EPI] <15 $\mathrm{mL} / \mathrm{min}$ ) and a serum urea of $185 \mathrm{mg} / \mathrm{dL}$ (normal $17-48 \mathrm{mg} / \mathrm{dL}$ ). Endogenous creatinine clearance was $33 \mathrm{~mL} / \mathrm{min}$. Intact parathyroid hormone was $580.3 \mathrm{ng} / \mathrm{L}$ (normal 15.0-65.0 $\mathrm{ng} / \mathrm{L}$ ). The sodium $140 \mathrm{mmol} / \mathrm{L}$, potassium $4.0 \mathrm{mmol} / \mathrm{L}$ and chloride $107 \mathrm{mmol} / \mathrm{L}$ concentrations were unremarkable. He had a pH of 7.30, bicarbonate of $18.2 \mathrm{mmol} / \mathrm{L}$, and $\mathrm{pCO}_{2}$ of 52.2 $\mathrm{mm} \mathrm{Hg}$. There was an albuminuria of $3.01 \mathrm{~g}$ albumin/g creatinine. The total proteinuria was $3.98 \mathrm{~g}$ protein/g creatinine. Serum creatine kinase (CK 5,995 U/L, normal <190 U/L; with CKMB activity $66.4 \mathrm{U} / \mathrm{L}$, normal $<24.0 \mathrm{U} / \mathrm{L})$ and myoglobin $(1,554 \mu \mathrm{g} / \mathrm{L}$, normal $28-72 \mu \mathrm{g} / \mathrm{L})$ were elevated. Serum albumin $(36 \mathrm{~g} / \mathrm{L})$ and protein $(64 \mathrm{~g} / \mathrm{L})$ levels were in the low-normal range. Serum cholesterol, low-density lipoprotein cholesterol, and high-density lipoprotein levels were 180,138, and $42 \mathrm{mg} / \mathrm{dL}$ under therapy with simvastatin, respectively. Autoimmune screen for antineutrophil cytoplasmic antibodies, extractable nuclear antigens, antinuclear antibodies, hepatitis, and human immunodeficiency virus serology were negative. Serum C3 and C4 complement-fraction levels were within normal limits. An electrocardiogram was normal. Renal ultrasound scanning showed kidneys with hyperechogenic renal parenchyma. The renal pyramids were not demarcated but a mildly extended renal pelvis was observed (Fig. 1a). The urine analysis exhibited few cells, hyaline casts, and heavy proteinuria. A renal biopsy was performed (Fig. 1b), consistent with advanced focal segmental glomerular sclerosis (FSGS). Is this patient merely an obese person with FSGS or is something else going on here?

\section{The Diagnosis}

Bodybuilding: consequences of anabolic steroids.

\section{Discussion}

The patient was a German professional bodybuilder who was not fat despite a BMI of 32 that classified him as an obese person (obesity class 2). He used progressive resistance exercise to develop his musculature from the age of 18-39 years. As part of his bodybuilding regimen, he consumed anabolic steroids, muscle growth-stimulating substances, and high-protein, low-fat diets. For more than 6 months until admission to our hospital, he resumed progressive resistance exercise and also regularly used anabolic androgenic steroids, including 


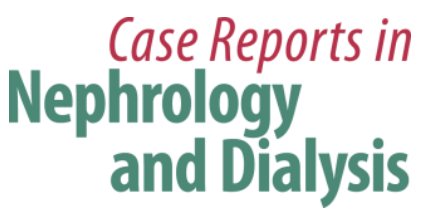

\begin{tabular}{l|l} 
Case Rep Nephrol Dial 2018;8:90-97 \\
\hline DOI: 10.1159/000489087 & $\begin{array}{l}\text { @ } 2018 \text { The Author(s). Published by S. Karger AG, Basel } \\
\text { www.karger.com/cnd }\end{array}$
\end{tabular}

Gollasch et al.: Chronic Kidney Disease Unmasked

testosterone enanthate (depot $250 \mathrm{mg} \times 2$ /week, i.m.), recombinant growth hormone (somatotropin $2 \times 2$ IU/day, i.m.), and boldenone $200 \mathrm{mg} \times 2 /$ week, i.m. In addition, he administered trenbolone enanthate (TrENOL 100) $100 \mathrm{mg} \times 1 /$ week, i.m. and methandienone (Metabolon) $10 \mathrm{mg} \times 3$ /day, p.o., and consumed a high-protein, low-fat diet: protein 1,326 kcal (42.8\%), carbohydrate 1,615 kcal (52.1\%), fat $160 \mathrm{kcal}$ (5.1\%), and vitamins, spread over 6 meals a day. Our patient reported intense training sessions within the past weeks.

The poet and play write, Berthold Brecht, once commented: "great sport begins when it has ceased to be healthy." Convincing athletes to adjust their behavior is difficult. Medical care is a function of compromises. After renal biopsy and diagnosis, our patient discontinued anabolic steroid abuse and muscle growth-stimulating substances. He continued resistance exercise training, but with less intensity. Figure 2 documents a decrease in serum CK in response to these changes, probably indicating reduced outflow from skeletal muscle to the blood stream by reduced exercise-related skeletal muscle damage [1], which can be severe in bodybuilders taking anabolic androgenic steroids [2]. Nevertheless, his renal function did not improve (Fig. 2). His high intact parathyroid hormone levels in the blood suggest that this increase was not an acute onset of FSGS, but rather a smoldering FSGS that developed over years. Our patient continued taking hydrochlorothiazide, telmisartan, and simvastatin. Home and ambulatory blood pressure monitoring showed that blood pressure was adequately controlled.

We followed anthropometric data over time with the air displacement plethysmography (BodPod) estimation. Over a 6-month period, his body mass hardly changed (from 96.6 to 98.4 $\mathrm{kg}$ ). His lean mass decreased from 88 to $72 \%$, while his body fat increased from 12 to $28 \%$. A combination of postadaptive glomerular changes driven by increased lean body mass [3] and potential direct nephrotoxic effects of anabolic steroids was mechanistically implicated and a guarded prognosis was reported $[4,5]$. Our patient's renal function failed to improve, despite a reduction in lean body mass, discontinuation of anabolic steroid drugs, and muscle growthstimulating substances (Fig. 2). Genetic factors could be of causal importance. We transferred our methodology for routine FSGS mutation screening (Sanger sequencing) to the Ion Torrent PGM platform with a new custom-targeted NGS gene panel (Ion Ampliseq FSGS panel). The NGS gene panel was validated in two patient cohorts with FSGS (see online suppl. material; for all online suppl. material, see www.karger.com/doi/10.1159/000489087). Using this approach, we did not detect mutations in our patient in the FSGS genes CD2AP, PLCE1, INF2, NPHS2, NPHS1, MYO1E, ACTN4, TRPC6, WT1, LMX1B, and LAMB2. Two common APOL1 G1 and G2 variants have been identified in populations of African ancestry as risk alleles for primary FSGS [6], which were irrelevant to our patient because of his Caucasian ancestry. We detected several common DNA variants occurring at a specific position in the FSGS genes (see online suppl. Table 1), which could represent candidates for renal risk variants in the differential diagnosis of secondary FSGS.

To our knowledge, an association between bodybuilding and FSGS is rare and has been reported in only three case studies, affecting a total of 12 Caucasian and Hispanic patients in the USA and Western Europe [4, 5, 7]. There are no reports concerning FSGS and bodybuilding in the Asian or African populations. However, we have no reason to believe that this form of secondary FSGS spares the Asian or African populations. 


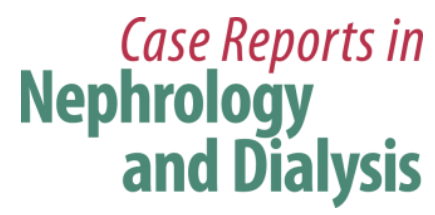

Case Rep Nephrol Dial 2018;8:90-97

DOI: $10.1159 / 000489087$

2018 The Author(s). Published by S. Karger AG, Base www.karger.com/cnd

Gollasch et al.: Chronic Kidney Disease Unmasked

One reported patient (index patient; see Table 1) resumed anabolic steroid abuse and suffered relapse of proteinuria and renal insufficiency [4]. However, whether this improvement in renal function (24-h creatinine clearance or Cockcroft-Gault estimate) was due to discontinuation of anabolic steroids, and/or reduction of weight loss, and/or pseudo normalization after discontinuation of dietary creatine supplements and/or reduced exercise-induced muscle damage is not entirely clear. Supplemental creatine ethyl ester is known to result in raised serum creatinine in the absence of true underlying kidney pathology $[8,9]$. We also used cystatin $\mathrm{C}$ to monitor renal function but failed to detect improvement of renal function (Fig. 2). Our patient was evaluated for preemptive kidney transplantation given his advanced chronic kidney disease. He declined to undergo arteriovenous fistula surgery.

Our patient resembled a 38-year-old bodybuilder [5] who presented with malignant hypertension and advanced FSGS requiring renal replacement therapy shortly after presentation. That patient also gave a history of prior abuse of anabolic steroids since the age 18 years, claiming to have stopped for a year or so prior to presentation. The authors suggest that anabolic steroid abuse is a direct cause of FSGS [5]. Our patient had long-standing hypertension, which per se is known as a risk factor for the development of secondary FSGS. Although ophthalmological examination showed no signs of hypertensive retinopathy in our patient, echocardiography revealed normal systolic left ventricular function (LVEF 60\%) and concentric left ventricular hypertrophy (relative wall thickness $>0.45$ ). Renal biopsy showed histological signs of long-standing hypertension, such as thickened vessel walls, hyalinosis, and tubulointerstitial fibrosis (see Table 1). These findings are consistent with long-standing hypertension in our patient. Any advanced kidney disease with substantial loss of nephrons is known to cause FSGS, and hypertension is viewed as a stress factor to develop the fully expressed phenotype of FSGS [10]. On the other hand, hypertension is common in FSGS and endstage renal disease, namely the current stage of chronic kidney failure of our patient. According to Herlitz et al. [4], patients with FSGS thought to be due to anabolic steroid use had a higher incidence of nephrotic syndrome at presentation and more advanced histological evidence of glomerulosclerosis than other patients with secondary FSGS. This finding is in keeping with the advanced biopsy findings in our patient, and the rapid progression to end-stage renal failure requiring dialysis in the bodybuilder described by Harrington et al. [5], who also had a long prior history of abuse of anabolic steroids. Anabolic steroids could possibly represent a cause of drug-induced secondary FSGS, independent of the patient's muscular physique. However, there are no experimental animal data to support this idea. Testosterone supplementation can induce podocyte apoptosis that precedes glomerulosclerosis in female estrogen receptor knockout mice [11]. Our patient also ingested boldenone, which per se can cause glomerulosclerosis, chronic renal injury, and progressive renal failure in rabbits [12]. However, histopathological analyses did not reveal signs of FSGS in both of the cited animal studies $[11,12]$. Our patient was also abusing growth hormone-related substances, such as insulinlike growth factor, which can promote glomerular extracellular matrix production independent of hemodynamic stimuli $[13,14]$. These compounds have also been discussed to play a role in secondary FSGS in nonobese patients with increased muscle mass [3]. However, it is unclear how relevant these effects are in human kidneys.

We conclude that increased BMI due to increased muscle mass and/or body fat in combination with long-term anabolic steroid use and growth-promoting substances should be included as risk factors in the differential diagnosis of secondary FSGS. Bodybuilders are a 


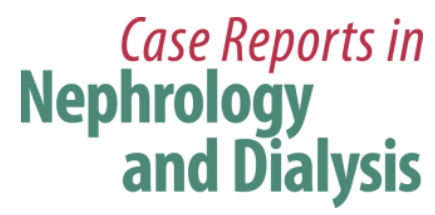

\begin{tabular}{l|l}
\hline Case Rep Nephrol Dial 2018;8:90-97 \\
\hline DOI: 10.1159/000489087 & $\begin{array}{l}\text { (c) 2018 The Author(s). Published by S. Karger AG, Basel } \\
\text { www.karger.com/cnd }\end{array}$
\end{tabular}

unique patient population that are fixated on their behavior. Simple counseling is well meaning; however, nephrologists may have to recruit other health care professionals when dealing with these patients. We are pursuing this option.

\section{Acknowledgments}

We thank Nadine Wittstruck for expert technical assistance. This study was supported by the Deutsche Forschungsgemeinschaft (DFG).

\section{Statement of Ethics}

The authors have no ethical conflicts to disclose. Our patient provided written, informed consent for our report and for the genetic testing performed.

\section{Disclosure Statement}

The authors have no financial or other conflict of interest to disclose.

\section{References}

1 Brentano MA, Umpierre D, Santos LP, Lopes AL, Radaelli R, Pinto RS et al. Muscle damage and muscle activity induced by strength training super-sets in physically active men. J Strength Cond Res. 2017 Jul;31(7):184758.

2 Nasseri A, Nadimi A, Nikookheslat SD. Effects of resistance exercise and the use of anabolic androgenic steroids on hemodynamic characteristics and muscle damage markers in bodybuilders. J Sports Med Phys Fitness. 2016 Sep;56(9):1041-6.

3 Schwimmer JA, Markowitz GS, Valeri AM, Imbriano LJ, Alvis R, D’Agati VD. Secondary focal segmental glomerulosclerosis in non-obese patients with increased muscle mass. Clin Nephrol. 2003 Oct;60 (4):233-41.

4 Herlitz LC, Markowitz GS, Farris AB, Schwimmer JA, Stokes MB, Kunis C et al. Development of focal segmental glomerulosclerosis after anabolic steroid abuse. J Am Soc Nephrol. 2010 Jan;21(1):163-72.

5 Harrington P, Ali G, Chan A. The development of focal segmental glomerulosclerosis secondary to anabolic steroid abuse. BMJ Case Rep. 2011 Dec;2011. https://doi.org/10.1136/bcr.07.2011.4531.

6 Kruzel-Davila E, Wasser WG, Skorecki K. Apol1 nephropathy: A population genetics and evolutionary medicine detective story. Semin Nephrol. 2017 Nov;37(6):490-507.

7 Hartung R, Gerth J, Fünfstück R, Gröne HJ, Stein G. End-stage renal disease in a bodybuilder: a multifactorial process or simply doping? Nephrol Dial Transplant. 2001 Jan;16(1):163-5.

8 Williamson L, New D. How the use of creatine supplements can elevate serum creatinine in the absence of underlying kidney pathology. BMJ Case Rep. 2014 Sep;2014. https://doi.org/10.1136/bcr-2014-204754.

9 Velema MS, de Ronde W. Elevated plasma creatinine due to creatine ethyl ester use. Neth J Med. 2011 Feb;69(2):79-81.

10 De Vriese AS, Sethi S, Nath KA, Glassock RJ, Fervenza FC. Differentiating primary, genetic, and secondary fsgs in adults: A clinicopathologic approach. J Am Soc Nephrol. 2018 Mar;29(3):759-74.

11 Doublier S, Lupia E, Catanuto P, Periera-Simon S, Xia X, Korach K et al. Testosterone and 17 $\beta$-estradiol have opposite effects on podocyte apoptosis that precedes glomerulosclerosis in female estrogen receptor knockout mice. Kidney Int. 2011 Feb;79(4):404-13. 
12 Alm-Eldeen A, Tousson E. Deterioration of glomerular endothelial surface layer and the alteration in the renal function after a growth promoter boldenone injection in rabbits. Hum Exp Toxicol. 2012 May;31(5):465-72.

13 Hirschberg R, Kopple JD. Effects of growth hormone and IGF-I on renal function. Kidney Int Suppl. 1989 Nov;27:S20-6.

14 Miller SB, Rotwein P, Bortz JD, Bechtel PJ, Hansen VA, Rogers SA et al. Renal expression of IGF I in hypersomatotropic states. Am J Physiol. 1990 Aug;259(2 Pt 2):F251-7.
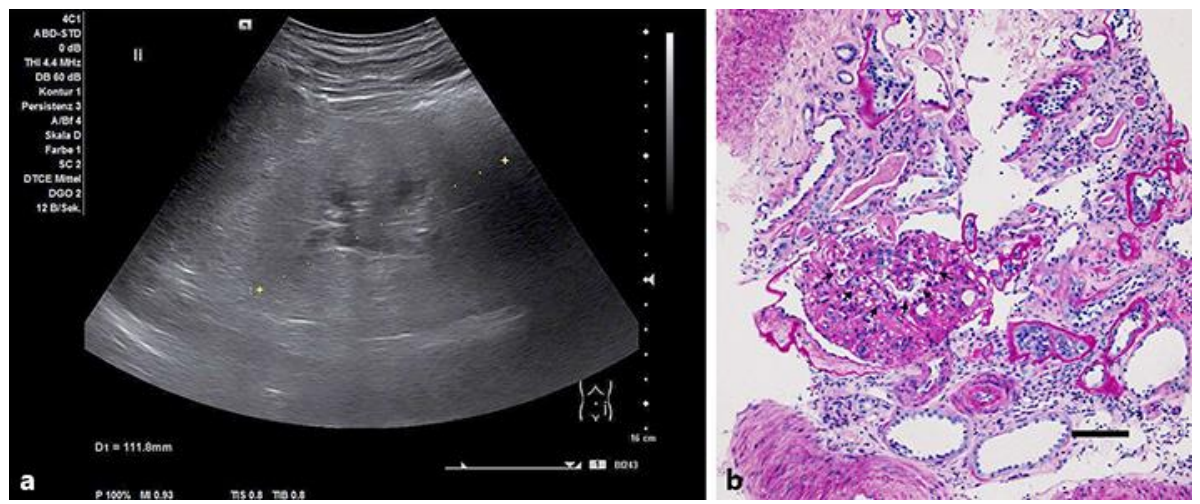

Fig. 1. Hyperechogenic renal parenchyma (a) and histology consistent with focal segmental glomerular sclerosis (b). Segmental obliteration of capillary loop basement membranes is marked by arrows. Periodic acid-Schiff. Scale bar, $50 \mu \mathrm{m}$. 


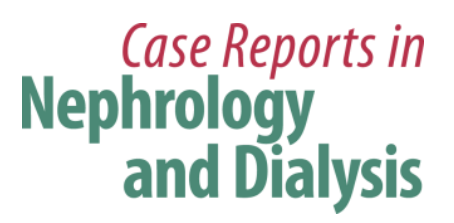

Case Rep Nephrol Dial 2018;8:90-97

DOI: 10.1159/000489087

Gollasch et al.: Chronic Kidney Disease Unmasked

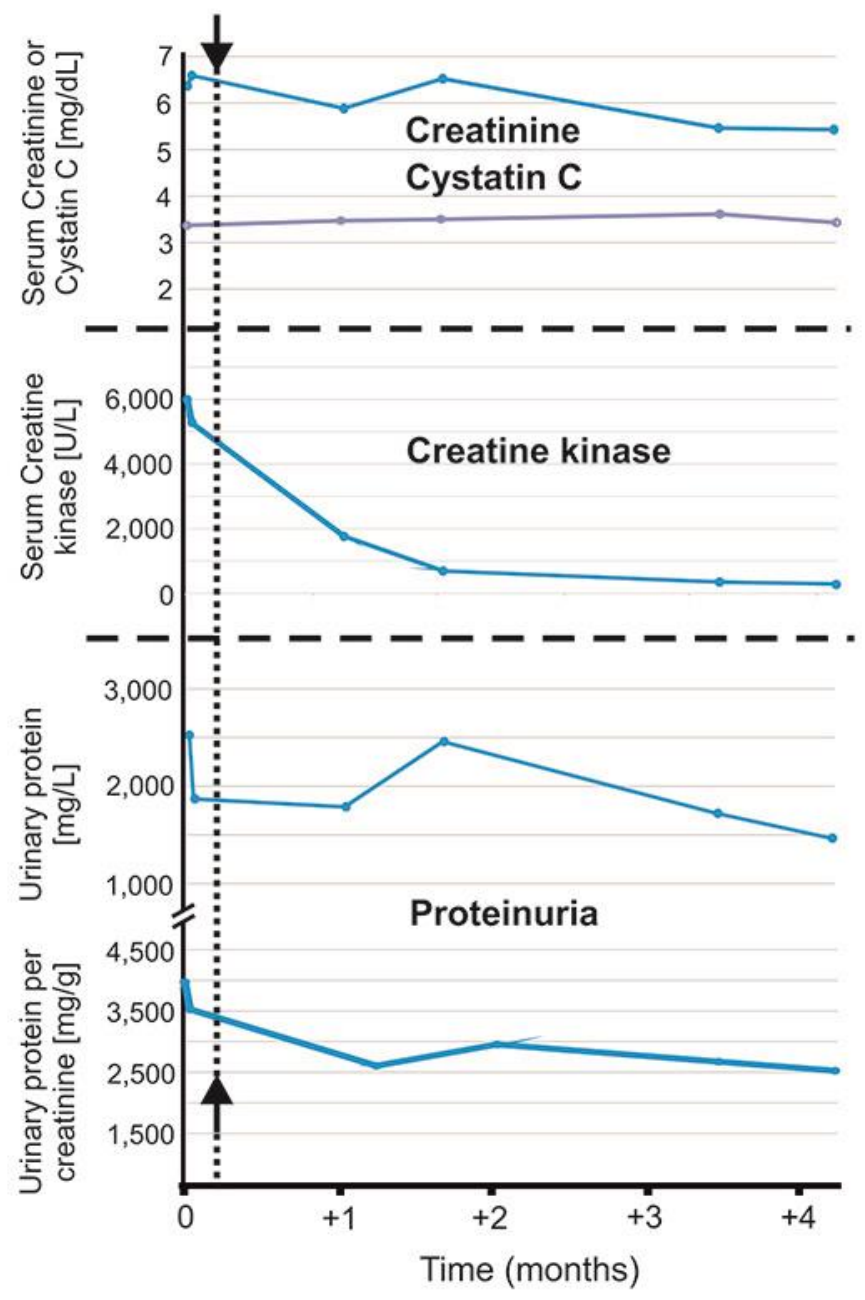

Fig. 2. Renal function, enzymes, and proteinuria showed little change over time. Arrows and dotted line indicate discontinuation of anabolic steroid abuse. 


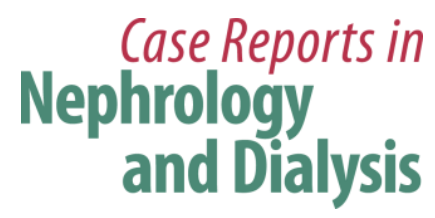

\begin{tabular}{l|l} 
Case Rep Nephrol Dial 2018;8:90-97 \\
\hline DOI: 10.1159/000489087 & $\begin{array}{l}\text { @ } 2018 \text { The Author(s). Published by S. Karger AG, Basel } \\
\text { www.karger.com/cnd }\end{array}$
\end{tabular}

Table 1. Pathologic findings in patients with FSGS associated with increased muscle mass

\begin{tabular}{|c|c|c|c|c|c|c|c|c|}
\hline & $\begin{array}{l}\text { Our } \\
\text { patient }\end{array}$ & $\begin{array}{l}\text { Index } \\
\text { patient } \\
\text { in [4] }\end{array}$ & $\begin{array}{l}\text { Eight } \\
\text { patients } \\
\text { in [4] }\end{array}$ & $\begin{array}{l}\text { Patient } 1 \text { in } \\
{[3]}\end{array}$ & $\begin{array}{l}\text { Patient } 2 \text { in } \\
\text { [3] }\end{array}$ & $\begin{array}{l}\text { Patient } 3 \text { in } \\
\text { [3] }\end{array}$ & $\begin{array}{l}\text { Index } \\
\text { patient } \\
\text { in [5] }\end{array}$ & $\begin{array}{l}\text { Index } \\
\text { patient } \\
\text { in [7] }\end{array}$ \\
\hline \multicolumn{9}{|l|}{ Light microscopy } \\
\hline Glomeruli & 8 & 22 & $6-61$ & 15 & 66 & 55 & $\mathrm{n} / \mathrm{r}$ & 12 \\
\hline Global sclerotic glomeruli & 3 & 16 & $0-16$ & 3 & 15 & 1 & $\mathrm{n} / \mathrm{r}$ & 10 \\
\hline Segmentally sclerotic glomeruli & 2 & 4 & $1-15$ & 1 & 10 & 0 & $\mathrm{n} / \mathrm{r}$ & 0 \\
\hline $\begin{array}{l}\text { Tubular atrophy and interstitial } \\
\text { fibrosis }\end{array}$ & $\begin{array}{l}\text { moderate } \\
(>50 \%)\end{array}$ & severe $(80 \%$ & $\begin{array}{l}\text { none-severe } \\
(80 \%)\end{array}$ & minimal & mild & none & $\mathrm{n} / \mathrm{r}$ & diffuse \\
\hline Interstitial inflammation & minimal & $\begin{array}{l}\text { mild-moder- } \\
\text { ate }\end{array}$ & $\mathrm{n} / \mathrm{r}$ & none & minimal & none & $\mathrm{n} / \mathrm{r}$ & $\mathrm{n} / \mathrm{r}$ \\
\hline Vascular disease & moderate & mild & $\begin{array}{l}\text { none-moder- } \\
\text { ate }\end{array}$ & -none & mild & minimal & $\mathrm{n} / \mathrm{r}$ & $\begin{array}{l}\text { pro- } \\
\text { nounced }\end{array}$ \\
\hline \multicolumn{9}{|l|}{ Electron microscopy } \\
\hline $\begin{array}{l}\text { Foot process effacement } \\
\text { Immune-type electron-dense }\end{array}$ & yes & yes & yes & yes & yes & yes & $\mathrm{n} / \mathrm{r}$ & $\mathrm{n} / \mathrm{r}$ \\
\hline deposits & no & no & $\mathrm{n} / \mathrm{r}$ & no & no & no & $\mathrm{n} / \mathrm{r}$ & $\mathrm{n} / \mathrm{r}$ \\
\hline Histopathological diagnosis & FSGS & FSGS & FSGS & FSGS & FSGS & FGGS & FSGS & FGGS \\
\hline ESRD at biopsy & no & no & $\begin{array}{l}1 / 9 \text { with fol- } \\
\text { low-up }\end{array}$ & no & no & no & yes & yes \\
\hline
\end{tabular}

Immunofluorescence was negative for IgG, IgM, IgA, C3, C1q, and kappa and lambda light chains in all patients. FSGS, focal segmental glomerulosclerosis, FGGS, focal global glomerulosclerosis. ESRF, end-stage renal failure. $\mathrm{n} / \mathrm{r}$, not reported. 